\title{
Trans-10, cis-12 conjugated linoleic acid reduces milk fat content and lipogenic gene expression in the mammary gland of sows without altering litter performance
}

\author{
E. C. Sandri ${ }^{1}$, K. J. Harvatine ${ }^{2}$ and D. E. Oliveira ${ }^{1 *}$ \\ ${ }^{1}$ Department of Animal Production, Santa Catarina State University, Lages, SC 88520-000, Brazil \\ ${ }^{2}$ Department of Animal Science, Penn State University, University Park, PA 16802, USA \\ (Submitted 3 September 2019 - Final revision received 5 December 2019 - Accepted 5 December 2019 - First published online 17 December 2019)
}

\section{Abstract}

Trans-10, cis-12 conjugated linoleic acid (CLA) decreases milk fat synthesis in lactating sows and involves, at least in part, the down-regulation of lipogenic genes. The objective was to evaluate the effect of CLA on milk composition and lipogenic gene expression. Twenty multiparous sows were randomly assigned to one of the two treatments for $18 \mathrm{~d}$ (from day 7 to day 25 of lactation): (1) control (no CLA added) and (2) $1 \%$ of CLA mixed into the ration. CLA treatment decreased milk fat and protein content by $20 \%(P=0.004)$ and $11 \%(P=0 \cdot 0001)$, respectively. However, piglet weight did not differ between treatments $(P=0 \cdot 60)$. Dietary CLA increased the concentration of SFA in milk fat by $16 \%(P<0.0001)$ and decreased MUFA by $17.6 \%(P<0 \cdot 0001)$. In the mammary gland, CLA reduced gene expression of acetyl-CoA carboxylase- $\alpha$ by $37 \%(P=0.003)$, fatty acid synthase by $64 \%(P=0.002)$, stearoyl-CoA desaturase 1 by $52 \%(P=0.003)$, lipoprotein lipase by $26 \%(P=0.03)$, acyl glycerol phosphate acyltransferase 6 by $15 \%(P=0.02)$ and diacylglycerol acyltransferase 1 by $27 \%(P=0.02)$, whereas the expression of fatty acid binding protein 3 was not altered by CLA treatment $(P=0.09)$. Mammary expression of casein- $\beta$ and $\alpha$-lactalbumin was reduced by CLA by $68 \%(P=0.0004)$ and $62 \%(P=0.005)$, respectively. Additionally, CLA had no effect on the expression of lipogenic genes evaluated in adipose tissue. In summary, CLA reduced milk fat content without negatively affecting litter performance and it affected mammary expression of genes involved in all lipogenic pathways studied.

\section{Key words: Fatty acid profile: Gene expression: Lipogenesis: Milk composition}

Conjugated linoleic acids (CLA) include positional and geometric isomers of octadecadienoic fatty acids with a conjugated double bond ${ }^{(1)}$. CLA naturally originates mainly from bacterial isomerisation and biohydrogenation of PUFA in the rumen and from the desaturation of vaccenic acid (trans-11-18:1) in the adipose tissue and mammary gland ${ }^{(2)}$. Although there are many isomers, cis-9, trans-11-CLA and trans-10, cis-12-CLA have received the most attention due to their known biological effects $^{(3)}$ and ability to chemically synthesise. Studies have revealed that the trans-10, cis-12-CLA isomer is responsible for milk fat depression in lactating cows ${ }^{(4)}$, ewes ${ }^{(5,6)}$, goats ${ }^{(7,8)}$, mice $^{(9)}$ and pigs ${ }^{(10,11)}$, while cis-9, trans-11-CLA has been proposed to have healthful properties for humans to combat cancer $^{(12,13)}$, inflammation ${ }^{(14)}$ and atherogenesis ${ }^{(15)}$.

In lactating sows, milk is the major source of nutrients for suckling piglets and their maximal growth performance and survival largely depend on enough milk being produced by sows ${ }^{(16)}$. Moreover, it has been documented that sows utilise energy from their body stores for milk production ${ }^{(17)}$, resulting in a loss of body weight (BW) during lactation ${ }^{(18)}$. Additionally, several studies have reported that BW loss during lactation reduces reproductive performance in the subsequent pregnancy ${ }^{(19,20)}$. Thus, it is important to minimise BW loss in sows during lactation as well as to maintain both maximal growth of piglets and subsequent reproductive performance ${ }^{(11)}$.

Feeding ruminants rumen-protected trans-10, cis-12-CLA supplements presents an opportunity to manipulate milk fat synthesis, since these supplements may improve the energy balance of lactating animals by reducing the amount of energy required for milk synthesis ${ }^{(21)}$. Spared energy can be partitioned towards the synthesis of other milk components ${ }^{(22)}$, or, alternatively, depending on the lactation period, it could also be used to replenish body fat reserves ${ }^{(23)}$, which may improve reproductive performance. Research at the cellular level has demonstrated a

Abbreviations: ACACA $\alpha$, acetyl-CoA carboxylase- $\alpha$; AGPAT6, acyl glycerol phosphate acyltransferase 6; BW, body weight; CLA, conjugated linoleic acid; DGAT1, diacylglycerol acyltransferase 1; FABP3, fatty acid binding protein 3; FASN, fatty acid synthase; LPL, lipoprotein lipase; SCD1, stearoyl-CoA desaturase 1.

* Corresponding author: D. E. de Oliveira, email dimas.oliveira@udesc.br 
coordinated down-regulation in the transcript abundance of genes involved in milk fat synthesis in the mammary gland of lactating cows ${ }^{(24)}$ and bovine mammary primary cells and cell lines ${ }^{(25)}$ and also in ewes ${ }^{(26)}$ and goats ${ }^{(27)}$, caused by supplementation with trans-10, cis-12-CLA.

However, the molecular mechanisms behind the inhibitory effect of trans-10, cis-12-CLA on mammary lipid synthesis in sows remain unclear. Therefore, we evaluated the effect of CLA on milk composition and also mammary and adipose lipogenic gene expression, mainly focusing on genes involved in the metabolism of fatty acids in the mammary gland and adipose tissue of lactating sows.

\section{Materials and methods \\ Animals, design and treatments}

All procedures were approved by the Santa Catarina State University Ethical Committee, protocol no. 3162250216, and were performed at a commercial farm in Concórdia City, SC $\left(27^{\circ} 14^{\prime} 03^{\prime \prime}\right.$ $\mathrm{S}$ and $\left.52^{\circ} 01^{\prime} 40^{\prime \prime} \mathrm{W}\right)$. Twenty multiparous sows from a commercial genotype (Aurora Genetics) in their 1st-5th parities and weighing (BW) 200 (SE 10) kg were randomly assigned to one of the following treatments: (1) control, without CLA added to the diet; or (2) $1 \%$ CLA (containing $4.1 \%$ palmitic acid, $3.6 \%$ stearic acid, $27.4 \%$ oleic acid, $1.2 \%$ linoleic acid, 29.8\% cis-9, trans-11-CLA, 29.9\% trans-10, cis-12-CLA and 3.0\% other fatty acids) mixed into the diet. The amount of CLA mixed into the feed was based on the procedure outlined in Lee et al. ${ }^{(11)}$.

\section{Management, feeding, experimental period, sampling and analysis}

The experimental period was $18 \mathrm{~d}$ and CLA feeding started on day 7 of lactation and was maintained till day 25 of lactation. The sows were moved into farrowing rooms after $108 \mathrm{~d}$ of gestation and were housed individually in pens $(2.2 \times 1.6 \mathrm{~m})$ with slatted floors and controlled temperature and relative humidity. Experimental diets were formulated according to the company to which the farm was integrated to meet the recommended nutrients required by the animals and contained ground maize (68.8\%), soyabean meal (23.2\%), a commercial vitamin/ mineral mix ( $5 \%$ ) and soyabean oil (3\%). The soyabean oil was replaced by CLA in the experimental treatment ( $1 \%$ of the total amount). The nutritional composition of diets contained, on average, $18 \%$ crude protein, $6.5 \%$ diethyl ether extract, $0.65 \%$ $\mathrm{Ca}, 0.5 \%$ total $\mathrm{P}, 2.7 \%$ fibre and $4.6 \%$ mineral matter. Sows were fed twice per $\mathrm{d}$ and received $7 \cdot 4(\operatorname{SE} 0 \cdot 1) \mathrm{kg} / \mathrm{d}$ (as fed) of the ration. Water access was ad libitum.

The number of piglets in each litter was adjusted (twelve piglets per sow) by cross-fostering piglets within $24 \mathrm{~h}$ of birth. Litters' weights were recorded immediately prior to initiation of CLA treatment (7th $\mathrm{d}$ of the lactation) and termination of treatment (25th $\mathrm{d}$ of lactation), and piglets were weaned at $28 \mathrm{~d}$ of age. In the first $5 \mathrm{~d}$ after birth, the litters were subjected to normal management procedures, including cutting of milk teeth, tail docking, ear notching, Fe shots and castration of males. At 2 weeks old, the litters began to receive supplemental dry feed for adaptation to a solid diet. The litters from both treatments received the same ration, and the intake was approximately $0 \cdot 80 \mathrm{~kg}$ (as fed) during this period.

Milk samples were collected on days 7 and 25 of lactation. Approximately $50 \mathrm{ml}$ of milk was obtained by manual stripping after intravenous injection of $0.5 \mathrm{ml}$ of oxytocin (Ocitovet $^{\circledR}$; Ceva Santé Animal). The samples were stored at $4^{\circ} \mathrm{C}$ with a preservative (Bronopol tablet; D \& F Control Systems Inc.). Milk fat, protein, lactose and total solids were determined by infrared analysis (method $972.160^{(28)}$ ) and fatty acid profile on day 25 as below.

Weaning-to-oestrus interval was determined by monitoring oestrus by daily exposure to a boar on days 3-7 after weaning.

\section{Milk fatty acid profile analysis}

Milk fatty acid profile was determined on milk collected on the last day of treatment (day 25 of lactation). Milk fat cake was obtained by centrifuging refrigerated milk at $3000 \mathrm{rpm}$ for $15 \mathrm{~min}$ at $4^{\circ} \mathrm{C}$. Approximately $50 \mathrm{mg}$ was then methylated following the methodology of O'Fallon et al. $^{(29)}$. The resulting fatty acid methyl esters (FAME) were determined using a GC (model Focus GC; Thermo Scientific) equipped with a flame ionisation detector and a fused silica capillary column SP-2560 ( $100 \mathrm{~m} \times 25 \mathrm{~mm} \times 0.2 \mu \mathrm{m}$ of film thickness; Supelco). $\mathrm{H}_{2}$ was used as a carrier gas $(1 \mathrm{ml} / \mathrm{min})$, and $\mathrm{N}_{2}$ was used as an auxiliary gas. Detector and injector temperatures were both set at $250^{\circ} \mathrm{C}$ with an injection split ratio of $15: 1$. Initial oven temperature was set to $70^{\circ} \mathrm{C}$ for $4 \mathrm{~min}$, was increased by $13^{\circ} \mathrm{C} / \mathrm{min}$ to $175^{\circ} \mathrm{C}$, at which point it was maintained for $27 \mathrm{~min}$, and then increased $4{ }^{\circ} \mathrm{C} / \mathrm{min}$ to $215^{\circ} \mathrm{C}$, where it was maintained for $31 \mathrm{~min}^{(30)}$. The FAME were identified by comparing with three FAME references (Supelco FAME mix no. C4-C24, trans-9, cis-11-CLA no. 16413 and trans-10, cis-12-CLA no. 04397; Sigma Aldrich). The cis/trans-18:1 isomers were identified according to their order of elution reported under the same chromatographic conditions ${ }^{(30)}$.

\section{Mammary and adipose tissue biopsies}

Mammary biopsies were taken on day 25 of lactation, after $18 \mathrm{~d}$ of treatment. A tranquiliser was administered $(2 \mathrm{ml} / \mathrm{sow}$ intramuscular and $6 \mathrm{ml} / \mathrm{sow}$ intravenous of Destress injectable; Des-Far Laboratories LDTA) to immobilise the animals, and lidocaine hydrochloride subdermal ( $2 \mathrm{ml} / \mathrm{sow}$ ) was then administered above the incision site. A coaxial needle with a trocar was introduced to the first or second thoracic mammary glands. The biopsy was collected using a Bard Max-Core Disposable Core Biopsy Instrument (Bard Biopsy Systems). Briefly, a 16-gauge biopsy needle was partially inserted through the coaxial needle and two tissue samples (approximately $35 \mathrm{mg}$ tissue/biopsy) were collected. These were inspected to verify tissue homogeneity, rinsed with saline solution, placed in cryotubes containing $1 \mathrm{ml}$ of Dulbecco's PBS (Gibco Laboratories) and were immediately stored in liquid $\mathrm{N}_{2}$ until RNA extraction. The biopsy procedure resulted in minimal bleeding and no intra-mammary infections were observed.

The adipose tissue biopsy was taken from the tail head region immediately cranial and lateral to the last lumbar vertebra (dorsal subcutaneous depot). Prior to the biopsy, site asepsis was performed and lidocaine hydrochloride subdermal was 
administered in a circular pattern surrounding the incision site $(2 \mathrm{ml} / \mathrm{sow})$. A small incision was made in the skin, and adipose tissue was dissected. Two samples of adipose tissue (approximately $100 \mathrm{mg}$ ) from the same site were obtained, rinsed with sterile saline solution, placed in cryotubes with PBS and frozen in liquid $\mathrm{N}_{2}$ until RNA extraction. The incision was closed with number 1 Nylon using a blanket stitch. After biopsies of adipose and mammary tissues, an anti-inflammatory was administered (flunixin meglumine; $1.1 \mathrm{mg} / \mathrm{kg}$ of $\mathrm{BW}$ ).

\section{RNA extraction, synthesis of complementary DNA and quantitative real-time $R T P C R$}

Total RNA extraction, synthesis of complementary DNA and quantitative real-time PCR (RT-qPCR) were all carried out according to the methodology of Sandri et al. ${ }^{(6)}$. Briefly, total RNA was extracted from both mammary and adipose tissue samples using the RNeasy Lipid Tissue Mini Kit (Qiagen Sciences) with on-column DNAse treatment (On-Column DNase I Digestion Set; Sigma-Aldrich). The RNA concentration was measured using a spectrophotometer (NanoDrop ND2000; NanoDrop Technologies), and using the same spectrophotometer, the quality was evaluated by the $\mathrm{A}_{260 / 280}$ ratio, which was approximately 2.03 (SE 0.01 ). Total RNA was transcribed to form complementary DNA using the GoScript ${ }^{\mathrm{TM}}$ Reverse Transcription Mix (Promega Corporation) with random primers. PCR amplification was performed in triplicates in a 48-well reaction plate (MicroAmp ${ }^{\mathrm{TM}}$; Applied Biosystems) with $15 \mu \mathrm{l}$ volume reaction with $30 \mathrm{ng}$ of complementary DNA and $7.5 \mu \mathrm{l}$ GoTaq qPCR Master Mix (Promega) in a StepOne Real-Time machine (Applied Biosystems) under the following conditions: $95^{\circ} \mathrm{C}$ for $2 \mathrm{~min}$, forty cycles of $95^{\circ} \mathrm{C}$ for $15 \mathrm{~s}, 62^{\circ} \mathrm{C}$ for $1 \mathrm{~min}$ and $95^{\circ} \mathrm{C}$ for $15 \mathrm{~s}$. The data were analysed using StepOne software version 2.1 (Applied Biosystems). All primers used were previously validated for the formation of a single product by melting curve and amplification efficiency. Each sample was run using seven-point standard curves with a 'pool' of complementary DNA from the mammary or adipose tissues with serial dilutions (100, 50, 25, 12.5, 6.25, 3.125 and $1.5625 \%$ ). Subsequently, a regression equation was generated by plotting the cycle threshold values from RT-qPCR against the log of each value from the standard curve. The slope of the equation was used to determine efficiency of the reaction.

\section{Primer design}

Gene sequences for primer designs were obtained from the gene bank of the National Center for Biotechnology Information (NCBI, USA). All primers were designed by the Prime-BLAST tool of NCBI, synthesised at Invitrogen ${ }^{\mathrm{TM}}$ and were tested for their efficiency before use. Expression of the following genes was measured: acetyl-CoA carboxylase- $\alpha$ $(A C A C A \alpha)$, fatty acid synthase (FASN), stearoyl-CoA desaturase 1 (SCD1), lipoprotein lipase ( $L P L)$, fatty acid binding protein 3 (FABP3), acyl glycerol phosphate acyltransferase 6 (AGPATO), diacylglycerol acyltransferase 1 (DGAT1), casein- $\alpha \mathrm{S} 1$, casein- $\beta$, casein- $\kappa$ and $\alpha$-lactalbumin. The primer sequences of the evaluated genes are listed in Table 1, and the description of the function of them is presented in online Supplementary Table S1.
Table 1. Swine primers used in the quantitative real-time RT PCR (RT-qPCR) analysis

\begin{tabular}{|c|c|c|c|}
\hline Symbols & Forward $(F)$ and reverse $(R)$ primer $^{\star}$ & $R^{2}$ & Efficienc) \\
\hline RPS18 & $\begin{array}{l}\text { F: CTGGCCAACGGTCTGGATAA } \\
\text { R: GGACACGCAGTCCCCAGAAG }\end{array}$ & 99.9 & 90.0 \\
\hline ACTB & $\begin{array}{l}\text { F: TCGCCGACAGGATGCAGAA } \\
\text { R: CCGATCCACACGGAGTACTTG }\end{array}$ & 99.5 & 108.0 \\
\hline$A C A C A \alpha$ & $\begin{array}{l}\text { F: CCTGCCCTAGCTTTCCAGTTAGAG } \\
\text { R: TGGCTGCCCCAAGGTACA }\end{array}$ & 99.9 & 93.6 \\
\hline FASN & $\begin{array}{l}\text { F: GAACCTGGAGGAGTTCTGGGC } \\
\text { R: ATCGTGTTCGCCTGCTTGGA }\end{array}$ & $99 \cdot 9$ & 90.0 \\
\hline$S C D 1$ & $\begin{array}{l}\text { F: GTGACCCTGGGCAAGTCATTTA } \\
\text { R: ACGCCTCAAAACTGCCCTTT }\end{array}$ & 99.7 & $99 \cdot 9$ \\
\hline$L P L$ & $\begin{array}{l}\text { F: AGATGTGGACCAGCTCGTGAA } \\
\text { R: GCACCGGTAGGCCTTACTAGGA }\end{array}$ & $99 \cdot 9$ & $93 \cdot 6$ \\
\hline$A B P 3$ & $\begin{array}{l}\text { F: CAAGCTGGGAGTGGAGTTTGAT } \\
\text { R: CCACTTCTGCACGTGGACAA }\end{array}$ & $99 \cdot 0$ & 99.0 \\
\hline$A G F$ & $\begin{array}{l}\text { F: CTCCCCACGTCTGGTTCGAA } \\
\text { R: AGGATGGGCAGCTTGCTTTT }\end{array}$ & $99 \cdot 0$ & 95.0 \\
\hline$D G A T 1$ & $\begin{array}{l}\text { F: GCCTGCAGGATTCTTTGTTCAG } \\
\text { R: AGCCGTGCATTGCTCAAGAC }\end{array}$ & $99 \cdot 0$ & 88.0 \\
\hline CSN1S1 & $\begin{array}{l}\text { F: GCCATGAGCAAAGGGGATCT } \\
\text { R: AGGCTCTCCCTGTTGGGTAT }\end{array}$ & $99 \cdot 0$ & $110 \cdot 1$ \\
\hline CSN2 & $\begin{array}{l}\text { F: GCCATGAAGCTCCTCATCCT } \\
\text { R: AGGCTTTCCACAGTCTCACC }\end{array}$ & $99 \cdot 0$ & 98.0 \\
\hline 13 & $\begin{array}{l}\text { F: TTTGGGTGCAGAGGAGCAAA } \\
\text { R: AGCTACAACTGGCCTTGCAT }\end{array}$ & 99.0 & 0 \\
\hline$\angle A L B A$ & $\begin{array}{l}\text { F: ATGTGAACACCCGCTGTCTT } \\
\text { R: GCACCAGTCACGCATCTCTA }\end{array}$ & $99 \cdot 0$ & $91 \cdot 0$ \\
\hline
\end{tabular}

RPS18, ribosomal protein S18; ACTB, $\beta$-actin; ACACA $\alpha$, acetyl-CoA carboxylase- $\alpha$; $F A S N$, fatty acid synthase; $S C D 1$, stearoyl-CoA desaturase 1; $L P L$, lipoprotein lipase; $F A B P 3$, fatty acid binding protein 3; AGPAT6, acyl glycerol phosphate acyltransferase 6; $D G A T 1$, diacylglycerol acyltransferase 1 ; CSN1S1, casein- $\alpha$ S1; CSN2, casein- $\beta$; CSN3, casein- $\kappa ;$ LALBA, $\alpha$-lactalbumin.

* Primers are reported as $5^{\prime}$ to $3^{\prime}$ sequence.

\section{Statistical analysis}

Data were analysed using the MIXED procedure in SAS ${ }^{(31)}$. Milk yield and concentration and yield of milk components were analysed using the MIXED procedure with day 'zero' as a covariate, treatment as a fixed effect and the individual animals as a random effect. The data for all genes of interest were normalised by the geometric mean of the reference genes ribosomal protein S18 and $\beta$-actin ${ }^{(32)}$, and the model for gene expression included the fixed effect of treatment and animal as a random effect.

Data points with Studentised residuals outside of \pm 2.5 were considered outliers and were excluded from analysis. When necessary, data were $\log _{2}$-transformed and back-transformed data are reported. Least-squares means (LSMEANS) were used to compare treatments, and significance was declared at $P<0.05$ and a trend at $P<0 \cdot 10$.

\section{Results}

Milk composition, litter performance and weaning-tooestrus interval

Milk composition, piglet weaning weight and weaning-tooestrus interval are presented in Table 2. Milk fat and protein concentration were decreased $20 \%(P=0.004)$ and $11 \%$ $(P<0.0001)$ by CLA, compared with the control. Milk casein content decreased $17 \%(P<0.0001)$ and total solids decreased $9.6 \%(P=0.0004)$ in the CLA treatment. There was also a trend for increased lactose content with CLA treatment $(P=0 \cdot 10)$. 
Table 2. Effect of trans-10, cis-12 conjugated linoleic acid (CLA) on milk composition, piglet weaning weight, and weaning-to-oestrus interval (WEI) of lactating sows

(Mean values with their pooled standard errors)

\begin{tabular}{lrrrc}
\hline & \multicolumn{2}{c}{ Treatments } & & \\
\cline { 2 - 3 } Variable & Control & CLA & SEM & $P^{*}$ \\
\hline Milk & 6.24 & 4.99 & 0.084 & 0.004 \\
Fat (\%) & 4.98 & 4.42 & 0.020 & $<0.0001$ \\
Protein (\%) & 5.68 & 5.81 & 0.018 & 0.10 \\
Lactose (\%) & 4.11 & 3.40 & 0.017 & $<0.0001$ \\
Casein (\%) & 18.07 & 16.34 & 0.087 & 0.0004 \\
Total solids (\%) & 7.80 & 7.90 & 0.043 & 0.60 \\
Piglet weaning weight (kg) & 4.10 & 4.40 & 0.109 & 0.50 \\
WEI (d) & & & &
\end{tabular}

* Overall effect of treatment.

Table 3. Effect of trans-10, cis-12 conjugated linoleic acid (CLA) on fatty acid (FA) composition (\% total FA)

(Mean values with their pooled standard errors)

\begin{tabular}{|c|c|c|c|c|}
\hline \multirow[b]{2}{*}{$F A(\%$ of $F A)$} & \multicolumn{2}{|c|}{ Treatments } & \multirow[b]{2}{*}{ SEM } & \multirow[b]{2}{*}{$P^{\star}$} \\
\hline & Control & CLA & & \\
\hline $8: 0$ & 0.08 & 0.09 & 0.073 & 0.59 \\
\hline $10: 0$ & 0.47 & 0.52 & 0.070 & 0.66 \\
\hline $12: 0$ & 0.60 & 0.63 & 0.017 & 0.66 \\
\hline $14: 0$ & 4.27 & $5 \cdot 21$ & 0.058 & 0.003 \\
\hline $14: 1$ & 0.28 & 0.15 & 0.006 & 0.0002 \\
\hline $16: 0$ & 31.78 & 33.84 & 0.314 & 0.16 \\
\hline $16: 1$ & 8.69 & 4.90 & 0.169 & 0.0001 \\
\hline $18: 0$ & 4.02 & 6.62 & 0.062 & $<0.0001$ \\
\hline $18: 1$ trans & 0.09 & 0.61 & 0.026 & 0.0004 \\
\hline $18: 1 n-9$ & $22 \cdot 70$ & $20 \cdot 30$ & 0.013 & 0.03 \\
\hline $18: 2 n-6$ & $20 \cdot 33$ & 17.44 & 0.282 & 0.03 \\
\hline $18: 3 n-3$ & 1.73 & 1.39 & 0.032 & 0.03 \\
\hline $20: 0$ & $0 \cdot 11$ & 0.14 & 0.001 & $<0.0001$ \\
\hline $20: 1 n-9$ & $0 \cdot 17$ & 0.17 & 0.046 & 0.89 \\
\hline $20: 2 n-6$ & 0.21 & 0.24 & 0.044 & 0.30 \\
\hline $20: 4 n-6$ & 0.29 & 0.31 & 0.008 & 0.03 \\
\hline cis-9, trans-11-CLA & 0.20 & 0.90 & 0.036 & 0.0004 \\
\hline trans-10, cis-12-CLA & $0.00 \dagger$ & 0.58 & 0.027 & - \\
\hline$\sum$ SFA $\ddagger$ & 41.39 & 48.00 & 0.266 & $<0.0001$ \\
\hline $\bar{\Sigma}$ MUFA & $32 \cdot 12$ & 26.49 & 0.201 & $<0.0001$ \\
\hline$\sum$ PUFA & 22.93 & 20.83 & 0.314 & 0.15 \\
\hline
\end{tabular}

* Overall effect of treatment.

$\dagger$ Trans-10, cis-12-CLA was not detected in the control treatment.

$\ddagger \sum$ SFA, $\sum$ MUFA, $\Sigma$ PUFA: sum of SFA, MUFA and PUFA, respectively.

There was no effect of CLA on weaning-to-oestrus interval or piglet weight. The litters from both treatments received the same ration at 2 weeks of age, and intake was approximately $0.80 \mathrm{~kg}$ (as fed basis) during this period.

\section{Milk fatty acid profile analysis}

Milk fatty acid compositions are shown in Table 3. Dietary CLA increased the concentration of $14: 0(P=0 \cdot 003), 18: 0$ $(P<0.0001)$, trans-18:1 $(P=0.0004)$, C20:0 $(P<0.0001)$, C20 : 4n-6 $(P=0.03)$ and cis-9, trans-11-CLA $(P=0.0004)$ and increased the proportion of SFA by $16 \%(P<0 \cdot 0001)$. In contrast, CLA reduced the concentration of $14: 1 \quad(P=0.0002)$, $16: 1 \quad(P=0.0001), 18: 1 n-9 \quad(P=0.03), 18: 2 n-6 \quad(P=0.03)$ and $18: 3 n-3(P=0.03)$ and decreased the proportion of

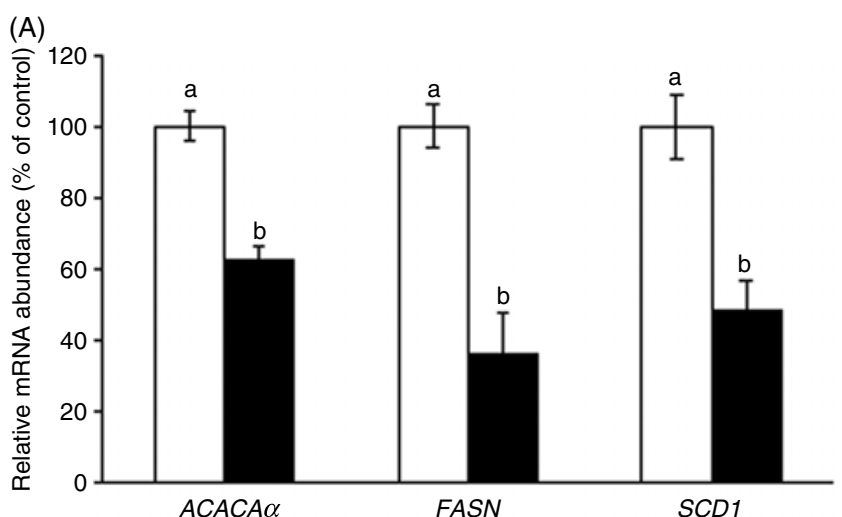

(B)
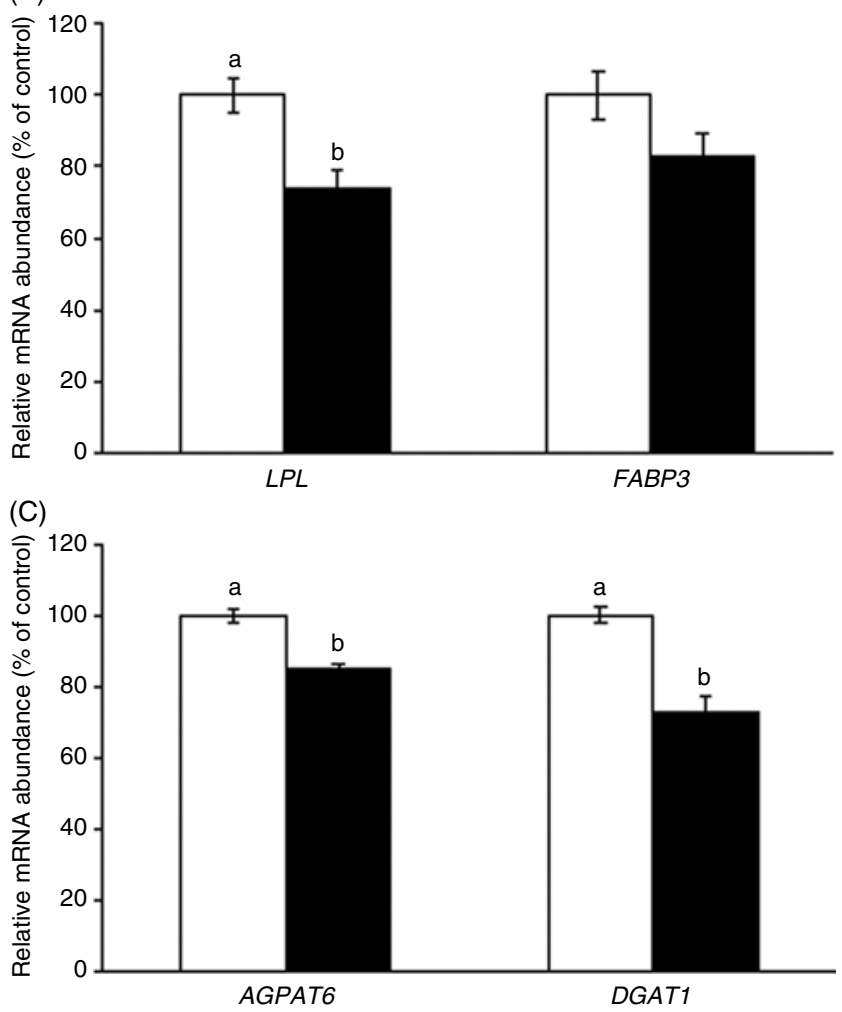

Fig. 1. Acetyl-CoA carboxylase- $\alpha$ (ACACA $\alpha$ ), fatty acid synthase (FASN), stearoyl-CoA desaturase 1 (SCD1) (A), lipoprotein lipase ( $L P L)$, fatty acid binding protein $3(F A B P 3)(B)$, acyl glycerol phosphate acyltransferase 6 (AGPAT6) and diacylglycerol acyltransferase 1 (DGAT1) (C) gene expression in the mammary gland of sows supplemented with trans-10, cis-12 conjugated linoleic acid $(\square)$, compared with control $(\square)$. Values are means with their standard errors. a,b Mean values with unlike letters were significantly different $(P<0.05)$.

MUFA by $17.6 \%(P<0 \cdot 0001)$. The CLA treatment did not alter total PUFA concentration.

As expected, the trans-10, cis-12-CLA isomer was not detectable in milk fat of the control; however, it was increased to $0.58 \%$ of fatty acids in the CLA treatment.

\section{Expression of lipogenic genes in mammary gland and adipose tissue}

In the mammary gland, CLA reduced mammary expression of $A C A C A \alpha$ by $37 \%(P=0.003), F A S N$ by $64 \%(P=0.002)$ and $S C D 1$ by $52 \%(P=0.003)$ (Fig. 1(A)). In genes involved 


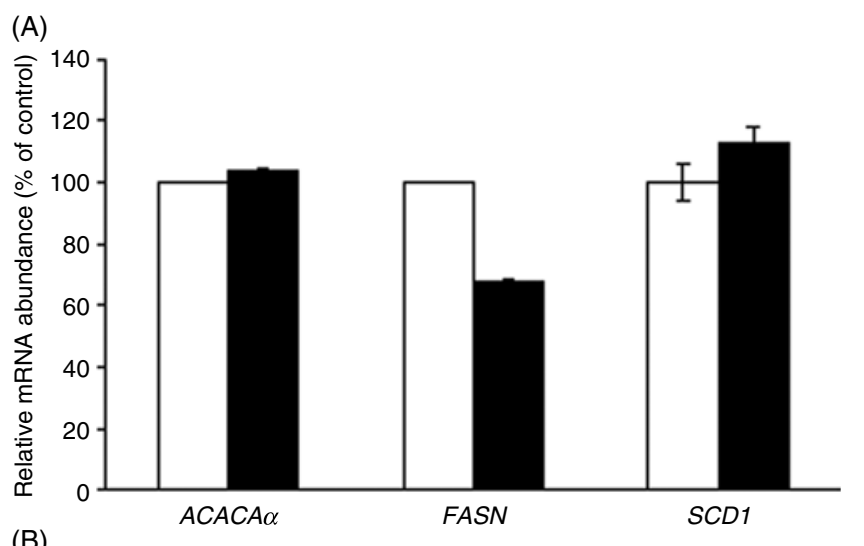

(B)

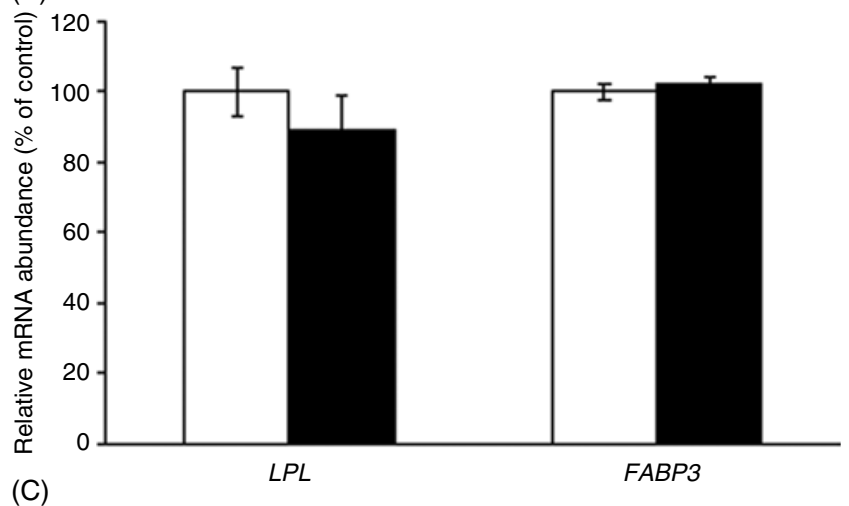

(C)

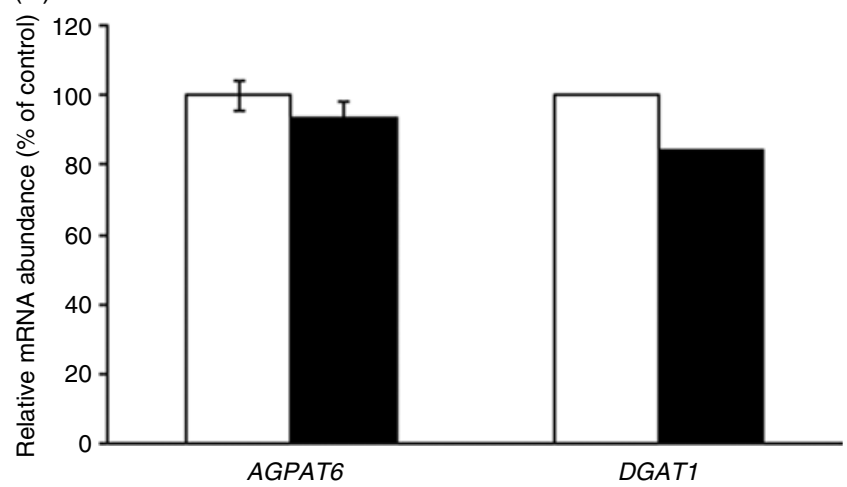

Fig. 2. Acetyl-CoA carboxylase- $\alpha(A C A C A \alpha)$, fatty acid synthase (FASM) stearoyl-CoA desaturase $1(S C D 1)(A)$, lipoprotein lipase ( $L P L)$, fatty acid binding protein $3(F A B P 3)(B)$, acyl glycerol phosphate acyltransferase 6 (AGPAT6) and diacylglycerol acyltransferase 1 (DGAT1) (C) gene expression in the adipose tissue of sows supplemented with trans-10, cis-12 conjugated linoleic acid $(\square)$, compared with control $(\square)$. Values are means with their standard errors.

in the uptake and transport of fatty acids, CLA reduced mammary $L P L$ expression by $26 \%(P=0.03$, Fig. $1(\mathrm{~B}))$, whereas CLA tended to reduce the expression of FABP3 $(P=0.09$, Fig. 1(B)). Finally, mammary expression of the TAG synthesis genes AGPAT6 was reduced by $15 \%(P=0.02)$, and DGAT1 was reduced $27 \%(P=0.02)$ (Fig. $1(C))$.

In adipose tissue, CLA treatment had no effect on the gene expression of all lipogenic genes evaluated ( $A C A C A \alpha$, $P=0.92 ; F A S N, P=0.67$ and SCD1, $P=0.80$, Fig. 2(A); $L P L$, $P=0.73$ and FABP3, $P=0.88$, Fig. 2(B); and AGPAT6, $P=0.69$ and $D G A T 1, P=0 \cdot 40$, Fig. $2(\mathrm{C})$ ).
Expression of genes coding for milk protein in mammary gland

Since milk protein was modified by CLA treatment (Table 2), the expression of individual milk protein genes was examined (Fig. 3). Among the caseins, CLA treatment reduced $\beta$-casein gene expression by $68 \%$, compared with the control $(P=0.0004)$ and reduced whey protein $\alpha$-lactalbumin expression by $62 \%(P=0 \cdot 005)$.

\section{Discussion}

Supplementing lactating sows with CLA reduced fat content in milk similar to previous studies. In the present study, the reduction in milk fat concentration was approximately $20 \%$, which is in accordance with the results of other studies in sows (approximately $\left.14-36 \%^{(33,34)}\right)$. Variation in responses may be due to the level and time of supplementation, the major isomer used, and the genotype and physiological state of the individual animals $^{(11)}$. A negative effect of CLA on milk protein content was observed in the present study. As milk protein concentration is positively associated with dietary energy content ${ }^{(35)}$, the CLA-induced reduction in energy level may have reduced milk protein synthesis. In addition, trans-10, cis-12-CLA, but not the cis-9, trans-11 isomer, stimulates expression of the mammalian target of rapamycin in the mammary gland of the sows before initiating lactation, and it effects protein synthesis in this species $^{(36,37)}$. As a mixture of these isomers was used, the milk protein reduction in the CLA-treated animals may be due to the isomer-specific action of cis-9, trans-11-CLA on mammalian target of rapamycin expression.

Unlike other studies, the weight of the piglets did not differ between the treatments. Corino et al $^{(38)}$ and Cordero et al. ${ }^{(33)}$ found increased weaning weight in piglets from sows receiving CLA, which may be a reflection of the increase in milk yield of the animals, which was not measured in our study. Moreover, the dry feed intake of the piglets was not different between treatments, and there was a trend for increased lactose content in CLA treatment (Table 2). As this is the drive for milk synthesis, we suggest that milk yield was increased by CLA treatment. Lastly, the weaning-to-oestrus interval of the sows was not affected by the treatments, which corroborates the work of Lee et $a l .{ }^{(11)}$.

Supplementation with CLA had a marked effect on milk fatty acid profile, with an increase in total SFA, a decrease in MUFA and no effect on total PUFA. These results are in agreement with those of previous studies ${ }^{(33,39)}$. The distinct shift towards higher SFA and lower MUFA synthesis indicate the potential downregulation of $S C D 1$ expression by dietary $C A^{(40)}$. This can be evidenced by the reduction in expression of lipid synthesis genes (Fig. 1(A)) and the effect observed on 16:1, a product of the 16:0 desaturation process through $S C D 1$, and by the observed reduction in $L P L$ expression (Fig. 1(B)), which hydrolyses and captures fatty acids from the diet. These observations may indicate a lower presence of these fatty acids in the milk and, consequently, a greater mobilisation of the reserve fatty acids, composed of SFA. 


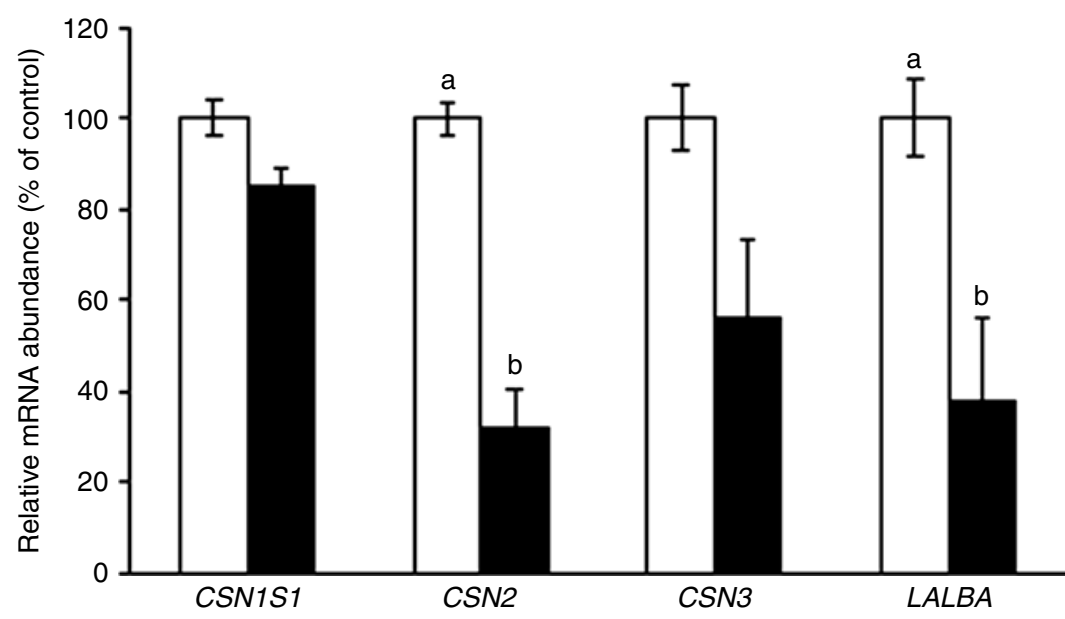

Fig. 3. Casein- $\alpha$ S1 (CSN1S1), casein- $\beta$ (CSN2), casein- $\kappa(C S N 3)$ and $\alpha$-lactalbumin (LALBA) gene expression in the mammary gland of sows supplemented with trans10, cis-12 conjugated linoleic acid $(\square)$, compared with control $(\square)$. Values are means with their standard errors. ${ }^{\text {a,b }}$ Mean values with unlike letters were significantly different $(P<0.05)$.

Another important aspect is that the concentration of milk fatty acids synthesised de novo in the mammary gland did not change or was increased with CLA treatment (e.g. 8:0, 10:0 and 12:0 were not modified, and 14:0 was increased by CLA), while the expression of the ACACA $\alpha$ and FASN genes, responsible for this synthesis pathway, was reduced by CLA. This discrepancy between the results may be explained by the presence of the enzyme thioesterase II in the mammary tissue of non-ruminants. Thioesterase II appears to function identically to thioesterase I in that it terminates the chain ${ }^{(41)}$. However, thioesterase II specificity differs, producing $8: 0$ to $14: 0$ fatty acids, meaning that fatty acid synthesis in the mammary gland is terminated at the level of myristic acid (14:0) rather than palmitic acid (16:0), as in other tissues ${ }^{(42)}$. Moreover, Duttaroy et al. ${ }^{(43)}$ investigated the effects of fatty acids on thioesterase activity in placental choriocarcinoma (BeWo) cells and found that its activity was increased by CLA, which could help explain the higher concentration of $14: 0$ in the CLA treatment. However, it is impossible to know how the de novo proportion of 16:0 was not impacted because it was not decreased even with higher termination at $14: 0$

Regarding the CLA isomers, the presence of trans-10, cis-12 isomer was not detectable in the control and because of this, it could not be analysed statistically. However, the isomer was present in the CLA treatment. The concentration of the cis-9, trans-11 isomer increased by more than 4-fold with CLA treatment. Given that the dietary CLA supplement contained the two isomers in similar proportions, studies have shown that the trans-10, cis-12 isomer is linked to a less efficient mechanism of incorporation into tissues than the cis-9, trans-11 isomer $^{(44,45)}$.

To our knowledge, this was the first study that evaluated effect of CLA on gene expression in mammary gland and adipose tissue of lactating sows; therefore, comparisons were made with ruminants or growing pigs. As in our study, previous works in cows, ewes and goats have established the anti-lipogenic effect of the trans-10, cis-12-CLA and have shown that its causes a reduction in the expression of genes involved in many lipid

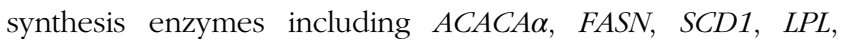
AGPAT and DGAT $24,27,46)$.

Our results revealed a more pronounced reduction in the expression of genes involved in de novo fatty acid synthesis (e.g. more than $60 \%$ reduction in $F A S N$ ), whereas the TAG synthesis genes and genes involved in the uptake and transport of preformed fatty acids were less affected. This was contrary to our hypothesis that genes related to preformed acids would be more affected by supplementation with CLA.

Spincer et $a l .{ }^{(47)}$ used the arteriovenous difference technique to identify milk precursors in lactating sows between the 5th and 6th week of lactation. Nutrients that had a high percentage of extraction from mammary gland included glucose (31\%), essential amino acids (22-38\%) and the TAG fatty acids, oleate (23\%) and palmitate (19\%). The percentage of extraction of NEFA ( $-6 \%)$ and $\beta$-hydroxybutyrate (11\%) suggested a minor role for these metabolites in milk synthesis. The authors proposed that the incorporation of preformed fatty acids appears to be less important quantitatively, suggesting that de novo synthesis of milk fat is greater in pigs and that it is formed from glucose as opposed to acetate and $\beta$-hydroxybutyrate as in ruminants ${ }^{(47)}$. Therefore, it is worth emphasising that synthesis from reserve fatty acids is more intense at the beginning of the lactation and as we evaluated the gene expression at the end of the lactation, consequently, in this period, de novo synthesis playing an important role in mammary lipogenesis and this can explain the greater response of the $A C A C A \alpha$ and $F A S N$ genes to CLA. This may have played a role in the relatively lower magnitude of reduction in $L P L$ expression, and in the observed tendency to reduce $F A B P 3$, compared with de novo synthesis genes.

The expression of the $F A B P 3$ gene was the only one unaffected by CLA in the mammary gland, and this corroborates with the results of Peterson et al. ${ }^{(48)}$ and Hussein et al. ${ }^{(46)}$. The aforementioned studies observed the same result in lactating cows and ewes receiving diets that induced milk fat depression (high concentrate/low forage) and that were supplemented with CLA, respectively. 
Among the FABP isoforms, Bionaz \& Loor ${ }^{(49)}$ confirmed the predominance of $F A B P 3$ in cow mammary gland, which has also been found in mice ${ }^{(50)}$ and other species ${ }^{(51)}$. According to Bionaz \& Loor ${ }^{(49)}$, the expression of $F A B P 3, F A B P 4$ and $F A B P 5$, the most abundant among the FABP isoforms, was up-regulated by the onset of lactation and increased greatly (1- to 78-fold) relative to their content prepartum. Among them, FABP3 is the most involved in bovine mammary lipid synthesis. We suggest that, just as the $F A B P 3$ is highly expressed in lactating cows, this could also be the same case in sows, to the point that the amount and period of CLA supplementation in the present study were not sufficient to cause a difference in its expression. In contrast, the lack of reduction in FABP3 may be due to the fact that the animals were in a positive energy balance and therefore fatty acid mobilisation from the reserves was not important.

In the adipose tissue, increased lipid synthesis during milk fat depression may be an indirect response to the reduction in energy required for milk fat synthesis ${ }^{(6)}$. Harvatine et al. ${ }^{(23)}$ observed that cows abomasally infused with trans-10, cis-12-CLA had increased gene expression of enzymes involved in lipid synthesis (FASN, SCD1 and FABP1) and of lipid synthesis regulatory transcription factors (PPAR $\gamma$ ) in adipose tissue, whereas fat synthesis decreased in the mammary gland. However, it is worth noting that in addition to a reduction in milk fat, there was a reduction in voluntary intake, resulting in an excess of available energy that was directed to adipose tissue. In our study, the voluntary intake was not measured as ration refusals were not observed, so there may not have been an excess of energy capable of stimulating greater fat synthesis in the adipose tissue, resulting in no changes in the expression of lipogenic genes in this tissue.

Specifically in pigs, some aspects must be taken into account: (1) in these animals, adipose tissue is the main site of lipogenesis ${ }^{(52)}$, and Duran-Montgé et al. ${ }^{(53)}$ observed that SFA were equivalent (or more potent) inhibitors of lipogenesis in the adipose tissue of pigs to unsaturated fatty acids, since the animals fed on the diet with highest SFA content tended to have decreased abundance of $A C A C A \alpha, F A S N$ and SCD1 mRNA, relative to other diets. Therefore, the CLA in the adipose tissue of the sows in our experiment would not have as potent an effect as in other species; (2) Zhou et al. ${ }^{(54)}$ observed that trans-10, cis-12-CLA, but not cis-9, trans-11-CLA, reduced the mRNA expression of adipocyte determination and differentiation factor-1, PPAR $\gamma$, adipocyte fatty acid binding protein and $L P L$ genes in subcutaneous adipose tissue cultures with a $6 \mathrm{~d}$ treatment. Therefore, when a mixture of isomers is used (as in the present study), different effects should be considered.

As a reduction in protein content was observed with CLA treatment, consequently the expression of $\beta$-casein and $\alpha$-lactalbumin genes was reduced. It is interesting to note that even with the reduction in $\alpha$-lactalbumin, one of the main routes of lactose synthesis, there was an increasing trend in lactose concentration. Lactose synthesis is a complicated process that requires the coordination of many genes encoding for enzymes involved in glucose uptake ${ }^{(55,56)}$, glucose-galactose interconversion ${ }^{(57)}$, uridine diphosphate galactose transportation ${ }^{(57,58)}$ and synthesis of lactose ${ }^{(50,59)}$. The synthesis itself occurs through lactose synthase composed of $\beta 1$,4-galactosyltransferase 1 and $\alpha$-lactalbumin, and according Zhang et al. ${ }^{(60)}$, the increased lactose synthesis related to the coordinated up-regulation of genes or enzymes involved in the lactose synthesis pathway, glucose transportation and lactose synthetase ( $\beta 1,4$-galactosyltransferase 1 and $\alpha$-lactalbumin) might be the critical step in the lactose synthesis pathway of sows during lactation. The reason why the lactose concentration trended to increase even with reduced expression of $\alpha$-lactalbumin is unclear but may involve other mechanisms of synthesis or a differentiated effect of CLA.

For being the first study of our group with lactating sows, and due to management and routine of the farm, some additional analyses could have been done, which eventually limited the interpretation of our results, such as milk collection, blood collection, biopsy at the beginning of the experimental period. Furthermore, for being also a first study on the trans-10, cis-12 CLA action on gene expression in the mammary gland in this animal species some points need to be better elucidated (e.g. mechanisms of action of the lipogenic genes and the lactation metabolism in sows) in order to extrapolate and to validate these results in future studies, including in humans.

\section{Conclusion}

CLA reduces the fat and protein content of milk in sows, without affecting the performance of the litter. The expression of genes involved in the lipogenic pathways evaluated was reduced by CLA in the mammary gland, and a greater expression intensity was observed for de novo synthesis genes. The reduction of genes coding for milk protein is a breakthrough in the present study.

\section{Acknowledgements}

The authors acknowledge the Coordenação de Aperfeiçoamento de Pessoal de Nível Superior (Capes) for the scholarship to E. C. S.. The authors also would like to thank Mr. Rafael Dallagnol and his family from Dallagnol Farm and Priscila C. Carraro for assistance.

The authors gratefully acknowledge the Conselho Nacional de Desenvolvimento Científico e Tecnológico - CNPq (grant no. 403731/2016-0 to D. E. O.) for the financial support.

The authors' contributions were as follows: E. C. S. and D. E. O. designed the research and E. C. S., D. E. O. and K. J. H. wrote the paper; E. C. S. conducted the animal experiment and data analysis with guidance from D. E. O. All authors read and approved the final manuscript.

The authors declare that they have no conflicts of interest.

\section{Supplementary material}

For supplementary material referred to in this article, please visit https://doi.org/10.1017/S0007114519003325

\section{References}

1. Bauman DE, Perfield JW, Harvatine KJ, et al. (2008) Regulation of fat synthesis by conjugated linoleic acid: lactation and the ruminant model. J Nutr 138, 403-409.

2. Griinari JM \& Bauman DE (1999) Biosynthesis of conjugated linoleic acid and its incorporation into meat and milk in 
ruminants. In Advances in Conjugated Linoleic Acid Research, pp. 180-200 [MP Yurawecz, MM Mossoba, JKG Kramer, et al., editors]. Champaign, IL: AOCS Press.

3. Hayashi AA, de Medeiros SR, Carvalho MH, et al. (2007) Conjugated linoleic acid (CLA) effects on pups growth, milk composition and lipogenic enzymes in lactating rats. $J$ Dairy Res 74, 160-166.

4. Baumgard LH, Corl BA, Dwyer DA, et al. (2000) Identification of the conjugated linoleic acid isomer that inhibits milk fat synthesis. Am J Physiol Regul Integr Comp Physiol 278, 179-184.

5. Oliveira DE, Gama MA, Fernandes D, et al. (2012) An unprotected conjugated linoleic acid supplement decreases milk production and secretion of milk components in grazing dairy ewes. J Dairy Sci $\mathbf{9 5}, 1437-1446$.

6. Sandri EC, Camêra M, Sandri EM, et al. (2017) Peroxisome proliferator-activated receptor gamma (PPAR $\gamma$ ) agonist fails to overcome trans-10, cis-12 conjugated linoleic acid (CLA) inhibition of milk fat in dairy sheep. Animal 12, 1405-1412.

7. Baldin M, Gama MA, Dresch R, et al. (2013) A rumen unprotected conjugated linoleic acid supplement inhibits milk fat synthesis and improves energy balance in lactating goats. J Anim Sci 91, 3305-3314.

8. Fernandes D, Gama MA, Ribeiro CV, et al. (2014) Milk fat depression and energy balance in stall-fed dairy goats supplemented with increasing doses of conjugated linoleic acid methyl esters. Animal 8, 587-595.

9. Loor JJ, Lin X \& Herbein JH (2003) Effects of dietary cis-9, trans11-18 : 2, trans-10, cis-12-18:2, or vaccenic acid (trans 11-18: 1) during lactation on body composition, tissue fatty acid profiles, and litter growth in mice. Br J Nutr 90, 1039-1048.

10. Poulos SP, Azain MJ \& Hausman GJ (2004) Conjugated linoleic acid (CLA) during gestation and lactation does not alter sow performance or body weight gain and adiposity in progeny. Anim Res 53, 275-288.

11. Lee SH, Joo YK, Lee JW, et al. (2014) Dietary conjugated linoleic acid (CLA) increases milk yield without losing body weight in lactating sows. J Anim Sci Technol 56, 11.

12. Ip C, Chin SF, Scimeca JA, et al. (1991) Mammary cancer prevention by conjugated dienoic derivative of linoleic acid. Cancer Res 51, 6118-6124.

13. Belury MA (2002) Inhibition of carcinogenesis by conjugated linoleic acid: potential mechanisms of action. I Nutr $\mathbf{1 3 2}$, 2995-2998.

14. Cook ME, Miller CC, Park Y, et al. (1993) Immune modulation by altered nutrient metabolism: nutritional control of immuneinduced growth depression. Poult Sci 72, 1301-1305.

15. Lee KN, Kritchevsky D \& Parizaa MW (1994) Conjugated linoleic acid and atherosclerosis in rabbits. Atherosclerosis 108, 19-25.

16. Wu G, Bazer FW, Wallace JM, et al. (2006) Intrauterine growth retardation: implications for the animal sciences. J Anim Sci $\mathbf{8 4}$, 2316-2337.

17. Noblet J \& Etienne M (1989) Estimation of sow milk nutrient output. J Anim Sci 67, 3352-3359.

18. Quesnel H, Etienne M \& Père MC (2007) Influence of litter size on metabolic status and reproductive axis in primiparous sows. J Anim Sci 85, 118-128.

19. Clowes EJ, Aherne FX, Foxcroft GR, et al. (2003) Selective protein loss in lactating sows is associated with reduced litter growth and ovarian function. J Anim Sci 81, 753-764.

20. Thaker MYC \& Bilkei G (2005) Lactation weight loss influences subsequent reproductive performance of sows. Anim Reprod Sci 88, 309-318.

21. Griinari JM \& Bauman DE (2006) Milk fat depression: concepts, mechanisms and management applications. In Ruminant Physiology: Digestion, Metabolism and Impact of Nutrition on Gene Expression, Immunology and Stress, pp. 389-417 [K Sejrsen, $\mathrm{T}$ Hvelplund and MO Nielsen, editors]. Wageningen: Wageningen Academic.

22. Medeiros SR, Oliveira DE, Aroeira LJ, et al. (2010) Effects of dietary supplementation of rumen-protected conjugated linoleic acid to grazing cows in early lactation. J Dairy Sci 93, 1126-1137.

23. Harvatine KJ, Perfield JW \& Bauman DE (2009) Expression of enzymes and key regulators of lipid synthesis is upregulated in adipose tissue during CLA induced milk fat depression in dairy cows. J Nutr 139, 849-854.

24. Baumgard LH, Matitasshvili E, Corl BA, et al. (2002) Trans-10, cis-12 conjugated linoleic acid decreases lipogenic rates and expression of genes involved in milk lipid synthesis in dairy cows. J Dairy Sci 85, 2155-2163.

25. Kadegowda AK, Bionaz M, Piperova LS, et al. (2009) Peroxisome proliferator-activated receptor- $\gamma$ activation and long-chain fatty acids alter lipogenic gene networks in bovine mammary epithelial cells to various extents. J Dairy Sci $\mathbf{9 2}$, 4276-4289.

26. Ticiani E, Urio M, Ferreira R, et al. (2016) Transcriptional regulation of acetyl-CoA carboxylase $\alpha$ isoforms in dairy ewes during conjugated linoleic acid induced milk fat depression. Animal 10, 1677-1683.

27. Shi H, Zhang T, Li C, et al. (2017) Trans-10, cis-12-conjugated linoleic acid affects expression of lipogenic genes in mammary glands of lactating dairy goats. I Agric Food Chem 65 , 9460-9467.

28. Association of Official Analytical Chemists (2000) Official Methods of Analysis, 17th ed. Arlington, VA: AOAC.

29. O'Fallon JV, Busboom JR, Nelson ML, et al. (2007) A direct method for fatty acid methyl ester (FAME) synthesis: application to wet meat tissues, oils and feedstuffs. J Anim Sci 85 , $1511-1521$.

30. Kraemer JK, Fellner V, Dugan ME, et al. (1997) Evaluating acid and base catalysts in the methylation of milk and rumen fatty acids with special emphasis on conjugated dienes and total trans fatty acids. Lipids 32, 1219-1228.

31. Statistical Analysis Software (SAS) (2013) User's Guide: Statistics, Version 9.4. Cary, NC: SAS Institute, Inc.

32. Vandesompele J, De Preter K, Pattyn F, et al. (2002) Accurate normalization of real-time quantitative RT-PCR data by geometric averaging of multiple internal control genes. Genome Biol 3 , $1-12$.

33. Cordero G, Isabel B, Morales J, et al. (2011) Conjugated linoleic acid (CLA) during last week of gestation and lactation alters colostrum and milk fat composition and performance of reproductive sows. Anim Feed Sci Technol 168, 232-240.

34. Harrell RJ, Phillips O, Boyd RD, et al. (2000) Effects of conjugated linoleic acid on milk composition and baby pig growth in lactating sows. J Anim Sci 78, 137-138.

35. Bocquier F \& Caja G (2001) Production and composition of ewe milk: feeding effects. INRA Prod Anim 14, 129-140.

36. Chung S, Brown JM, Sandberg MB, et al. (2005) Trans-10, cis-12 CLA increases adipocyte lipolysis and alters lipid dropletassociated proteins: role of mTOR and ERK signaling. J Lipid Res 46, 885-895.

37. Manjarín R, Steibel JP, Kirkwood RN, et al. (2012) Transcript abundance of hormone receptors, mammalian target of rapamycin pathway-related kinases, insulin-like growth factor I, and milk proteins in porcine mammary tissue. J Anim Sci $\mathbf{9 0}$, 221-230.

38. Corino C, Pastorelli G, Rosi F, et al. (2009) Effect of dietary conjugated linoleic acid supplementation in sows on performance and immunoglobulin concentration in piglets. J Anim Sci 87, 2299-2305. 
39. Bee G (2000) Dietary conjugated linoleic acids alter adipose tissue and milk lipids of pregnant and lactating sows. $J$ Nutr 130, 2292-2298.

40. Smith SB, Hively TS, Cortese GM, et al. (2002) Conjugated linoleic acid depresses the $\Delta^{9}$ desaturase index and stearoyl coenzyme A desaturase enzyme activity in porcine subcutaneous adipose tissue. J Anim Sci 80, 2110-2115.

41. Smith S (1994) The animal fatty acid synthase: one gene, one polypeptide, seven enzymes, FASEB J 8, 1248-1259.

42. Chen ZY, Pelletier G, Hollywood R, et al. (1995) Trans fatty acid isomers in Canadian human milk. Lipids 30, 15-21.

43. Duttaroy AK, Crozet D, Taylor J, et al. (2003) Acyl-CoA thioesterase activity in human placental choriocarcinoma (BeWo) cells: effects of fatty acids. Prostaglandins Leukot Essent Fatty Acids 68, 43-48.

44. Fiego DP, Macchioni P, Santoro P, et al. (2005) Effect of dietary conjugated linoleic acid (CLA) supplementation on CLA isomers content and fatty acid composition of dry-cured Parma ham. Meat Sci 70, 285-291.

45. Ostrowska E, Cross RF, Muralitharam M, et al. (2003) Dietary conjugated linoleic acid differentially alters fatty acid composition and increases conjugated linoleic acid content in porcine adipose tissue. BrJ Nutr $\mathbf{9 0}$, 915-928.

46. Hussein M, Harvatine KH, Weerasinghe WM, et al. (2013) Conjugated linoleic acid-induced milk fat depression in lactating ewes is accompanied by reduced expression of mammary genes involved in lipid synthesis. J Dairy Sci $\mathbf{9 6}$, 3825-3834.

47. Spincer J, Rook JAF \& Towers KG (1969) The uptake of plasma constituents by the mammary gland of the sow. Biochem J111, 727-732.

48. Peterson DG, Matitashvili EA \& Bauman DE (2003) Dietinduced milk fat depression in dairy cows results in increased trans-10, cis-12 CLA in milk fat and coordinate suppression of mRNA abundance for mammary enzymes involved in milk fat synthesis. J Nutr 133, 3098-3102.

49. Bionaz M \& Loor JJ (2008) ACSL1, AGPAT6, FABP3, LPIN1, and SLC27A6 are the most abundant isoforms in bovine mammary tissue and their expression is affected by stage of lactation. J Nutr 138, 1019-1024.

50. Rudolph MC, McManaman JL, Phang T, et al. (2007) Metabolic regulation in the lactating mammary gland: a lipid synthesizing machine. Physiol Genomics 28, 323-336.

51. Haunerland NH \& Spener F (2004) Fatty acid-binding proteins-insights from genetic manipulations. Prog Lipid Res 43, 328-349.

52. O'Hea EK \& Leveille GA (1969) Significance of adipose tissue and liver as sites of fatty acid synthesis in pig and efficiency of utilization of various substrates for lipogenesis. J Nutr $\mathbf{9 9}$, 338-344.

53. Duran-Montgé P, Theil PK, Lauridsen C, et al. (2009) Dietary fat source affects metabolism of fatty acids in pigs as evaluated by altered expression of lipogenic genes in liver and adipose tissues. Animal 3, 535-542.

54. Zhou X, Li D, Yin J, et al. (2007) CLA differently regulates adipogenesis in stromal vascular cells from porcine subcutaneous adipose and skeletal muscle. J Lipid Res $\mathbf{4 8}$, 1701-1709.

55. Kuhn NJ \& White A (2009) The topography of lactose synthesis. J Mammary Gland Biol Neoplasia 14, 213-220.

56. Zhao FQ (2014) Biology of glucose transport in the mammary gland. J Mammary Gland Biol Neoplasia 19, 3-17.

57. Mohammad MA, Hadsell DL \& Haymond MW (2012) Gene regulation of UDP-galactose synthesis and transport: potential rate-limiting processes in initiation of milk production in humans. Am J Physiol Endocrinol Metab 303, 365-376.

58. Kuhn NJ \& White A (1977) The role of nucleoside diphosphatase in a uridine nucleotide cycle associated with lactose synthesis in rat mammary gland Golgi apparatus. Biochem J 168, 423-433.

59. Neville MC (2009) Introduction: alpha-lactalbumin, a multifunctional protein that specifies lactose synthesis in the Golgi. J Mammary Gland Biol Neoplasia 14, 211-212.

60. Zhang Y, Zhang S, Guan W, et al. (2018) GLUT1 and lactose synthetase are critical genes for lactose synthesis in lactating sows. Nutr Metab 15, 40. 